\title{
Photocatalytic Activity and Mechanical Properties of Cements Modified with $\mathrm{TiO}_{2} / \mathrm{N}$
}

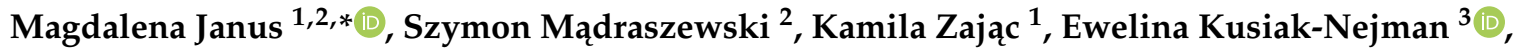 \\ Antoni W. Morawski ${ }^{3}$ (D) and Dietmar Stephan ${ }^{2}$ (D) \\ 1 Faculty of Civil Engineering and Architecture, West Pomeranian University of Technology, Szczecin, al. \\ Piastów 50, 70-311 Szczecin, Poland; kamila.zajac@zut.edu.pl \\ 2 Building Materials and Construction Chemistry, Technische Universität Berlin, Gustav-Meyer-Allee 25, \\ 13355 Berlin, Germany; szymon.madraszewski@tu-berlin.de (S.M.); stephan@tu-berlin.de (D.S.) \\ 3 Faculty of Chemical Technology and Engineering, West Pomeranian University of Technology, Szczecin, ul. \\ Pułaskiego 10, 70-310 Szczecin, Poland; ewelina.kusiak@zut.edu.pl (E.K.-N.); amor@zut.edu.pl (A.W.M.) \\ * Correspondence: mjanus@zut.edu.pl; Tel.: +48-91-449-4083
}

Received: 30 September 2019; Accepted: 12 November 2019; Published: 14 November 2019

\begin{abstract}
In this paper, studies of the mechanical properties and photocatalytic activity of new photoactive cement mortars are presented. The new building materials were obtained by the addition of 1,3 , and $5 \mathrm{wt} \%$ (based on the cement content) of nitrogen-modified titanium dioxide $\left(\mathrm{TiO}_{2} / \mathrm{N}\right)$ to the cement matrix. Photocatalytic active cement mortars were characterized by measuring the flexural and the compressive strength, the hydration heat, the zeta potential of the fresh state, and the initial and final setting time. Their photocatalytic activity was tested during NOx decomposition. The studies showed that $\mathrm{TiO}_{2} / \mathrm{N}$ gives the photoactivity of cement mortars during air purification with an additional positive effect on the mechanical properties of the hardened mortars. The addition of $\mathrm{TiO}_{2} / \mathrm{N}$ into the cement shortened the initial and final setting time, which was distinctly observed using $5 \mathrm{wt} \%$ of the photocatalyst in the cement matrix.
\end{abstract}

Keywords: photoactive cement; $\mathrm{TiO}_{2} / \mathrm{N}$; NOx decomposition; mechanical properties

\section{Introduction}

In the last few decades, nanoparticles have been considered as an additive to the concrete and related cement products in order to improve the properties of building materials [1]. The first documented addition of the nanoparticles to a cement-based system occurred in 1964 when the nano- $\mathrm{SiO}_{2}$ facilitated a faster and more complete hydration of cement [2]. However, the application of various nanoparticles, such as nano- $\mathrm{TiO}_{2}$, nano- $\mathrm{Al}_{2} \mathrm{O}_{3}$, and nano- $\mathrm{Fe}_{2} \mathrm{O}_{3}$ in cement and concrete materials has developed intensively since circa 2004 [3-5]. Combining $\mathrm{TiO}_{2}$ nanoparticles with cementitious binders appeared to be one of the most promising ways to obtain environmentally friendly products [6]. Namely, a $\mathrm{TiO}_{2}$ photocatalyst, when activated by the suitable light, is capable of supporting the chemical reactions, which can degrade an atmospheric pollutant and give a self-cleaning property [7]. It is worth pointing out that the building surfaces are exposed to the highest levels of air pollution and at the same time to the solar radiation, which is necessary in photocatalytic processes.

In the urban areas, $\mathrm{NOx}\left(\mathrm{NO}+\mathrm{NO}_{2}\right)$ is one of the most common pollutants from the external sources (traffic, industry) [8]. NOx contributes to the formation of the photochemical smog, and it is associated with lung problems and asthma [9]. The potential of cementitious materials containing photocatalysts to decrease the NOx concentration was proven many times [10-12]. For example, Lee et al. [13] studied changes in $\mathrm{NO}$ and $\mathrm{NO}_{2}$ concentration using $\mathrm{TiO}_{2}$-containing cement-based materials during UV irradiation, suggesting that the materials are capable of oxidizing both gases 
efficiently. It was observed the similar amounts of $\mathrm{NO}$ and $\mathrm{NO}_{2}$ gases were degraded at $3 \mathrm{~h}$, regardless of the variations in the water/cement ratio. The mechanism of NOx degradation consists of a series of reactions that take place during the photocatalytic process. Typically, it can be described as a sequential oxidation process, as follows: $\mathrm{NO} \rightarrow \mathrm{HNO}_{2} \rightarrow \mathrm{NO}_{2}{ }^{-} \rightarrow \mathrm{NO}_{3}{ }^{-}[8,11]$.

Many works in the photocatalytic branch are directed at modification of the base $\mathrm{TiO}_{2}$ structure through doping of the photocatalyst with the non-metals or the metal ions [14,15]. Mainly, it can enhance its activation in the visible light [16], but other advantages are also observed. In the treatment of $\mathrm{NOx}$, modifications of $\mathrm{TiO}_{2}$ can improve the catalytic selectivity toward nitrate rather than the more toxic $\mathrm{NO}_{2}$ [7].

Although the photocatalytic cements and concretes have been extensively studied [17], it is still controversial whether the added photocatalyst enhances building properties. On the one hand, the presence of $\mathrm{TiO}_{2}$ nanoparticles can have a positive filler effect in cement mortars, increasing the mechanical strengths. One of the reported best performance enhancement results of the inclusion of $\mathrm{TiO}_{2}$ nanoparticles in the cementitious materials included a $45 \%$ increase in the compressive strength [18] and an 87\% increase in the flexural strength [19]. Yang et al. [20] indicated that the addition of $0.5 \mathrm{wt} \% \mathrm{TiO}_{2}$ to cement slag pastes allowed achieving approximately $10 \%, 15 \%$, and $9 \%$ higher compressive strengths in comparison to the reference material at $3 \mathrm{~d}, 7 \mathrm{~d}$, and $28 \mathrm{~d}$, respectively. Meanwhile, the flexural strengths of the same photocatalytic materials were $25 \%, 25 \%$, and $38 \%$ higher than the reference sample after the same range time of the curing. On the other hand, researchers also observed [21,22] a slight decrease in the mechanical strength of the photocatalytic cement mortars, which has been attributed to the decline of the sample's homogeneity and the formation of weak zones in the structure of hardened mortars.

Some authors [7] indicated that the effective use of photocatalysts in cement is highly connected with the assurance of the optimized dispersion of $\mathrm{TiO}_{2}$ particles in the cement matrix. The agglomeration of $\mathrm{TiO}_{2}$ particles can interfere not only with the mechanical strength, but also block access to an internal surface of $\mathrm{TiO}_{2}$, limiting the photocatalytic efficiency. The degree of repelling between particles of cement mortars has a direct relationship with "zeta potential", which shows the electrokinetic behavior of particles and gives a valuable indication of the surface charge state, achieving values from $-30 \mathrm{mV}$ to $+30 \mathrm{mV}[23,24]$. When the constituent particles of mortars have the same charge, they tend to repeal each other, and no agglomeration occurs. Up to now, the zeta potential measurements of cementitious materials have been performed with a low fraction of solid. Therefore, it is challenging to obtain information about the zeta potential values of real fresh cement mortars and even more so referring to photocatalytic cement mortars. Lowke and Gehlen [24] considered the zeta potential of Portland cement and mineral additions in cement suspensions with high solid fractions. They found a continuous increase in the zeta potential of cementitious suspensions with the increasing $\mathrm{w} / \mathrm{c}$ ratio (water/cement). Moreover, the determining factor on the zeta potential appeared to be the molar $\mathrm{Ca} / \mathrm{SO}_{4}$ concentration ratio, which was more crucial than the effect of the type of addition.

The absolute values of zeta potential may vary not only with mortar composition or w/c ratio but also with the time of hydration [25]. The hydration mechanism of cement consists of the reactions of cement components (e.g., alite or tricalcium silicate, belite or dicalcium silicate) with water. The formed crystalline calcium hydroxide and calcium-silicate-hydrate (C-S-H) comprise over $60 \mathrm{wt} \%$ of the hydration products in the total mass [26]. As the reactions continue with time, the hydration products gradually bind together and with other components of concrete to form a solid mass. The hydration of cement is an exothermic chemical reaction. The generation of heat is highly determined by the chemical composition of the cement mixture. It was reported that nanoparticles of $\mathrm{TiO}_{2}$ could significantly change the hydration of cement and influence the rates of heat evolution $[27,28]$. The cement hydration is directly related to the setting time of cement mortars. Mostly, the photocatalytic cements showed a shortened initial and final setting time for the samples with higher $\mathrm{TiO}_{2}$ contents, which is attributed to the acceleration of the hydration rate [29]. 
The aim of this paper is to present the results of our study on the influence of a prepared $\mathrm{TiO}_{2} / \mathrm{N}$ photocatalyst on the properties of the fresh and hardened cement mortars. $\mathrm{TiO}_{2} / \mathrm{N}$ was chosen as the photocatalyst because there is the possibility of producing this material in the amount of $0.5 \mathrm{~kg}$ per day. Moreover, the technological project of installation for $\mathrm{TiO}_{2} / \mathrm{N}$ production exists and may be used for photocatalyst production at a large scale. The photocatalyst has been added in different dosages $(1,3$, and $5 \mathrm{wt} \%$ to cement mass) to cement mortars. The measurements of the initial and the final setting time, the flexural and the compressive strength, the hydration heat, and the zeta potential were conducted. The photocatalytic activity was monitored during the NOx degradation process.

\section{Materials and Methods}

\subsection{Materials}

Ordinary Portland cement CEMI $42.5 \mathrm{~N}$ from Holcim, Germany was used in this study. Standard sand, according to EN 196-1, was used for all mortars.

The preparation of the photocatalyst $\left(\mathrm{TiO}_{2} / \mathrm{N}\right)$ was carried out using HEL Ltd. "Autolab" E746 installation. The commercial titanium dioxide supplied by Grupa Azoty Zakłady Chemiczne 'Police' S.A. (Poland) was used as a starting material. First, $600 \mathrm{~g}$ of $\mathrm{TiO}_{2}$ and $350 \mathrm{~mL}$ of $\mathrm{NH}_{4} \mathrm{OH}$ with a concentration of $2.5 \%$ were placed in an autoclave. The reactor was closed, and the mixture was blended using a magnetic stirrer and heated up to $100^{\circ} \mathrm{C}$ for $4 \mathrm{~h}$. Afterwards, the catalyst was dried in air for $4 \mathrm{~h}$ at $100{ }^{\circ} \mathrm{C}$. Finally, the obtained photocatalyst $\mathrm{TiO}_{2} / \mathrm{N}$ was ground with mortar to form a fine powder. The structural and the textural parameters on $\mathrm{N}$-modified $\mathrm{TiO}_{2}$ in Table 1 were placed. The results of TEM (transmission electron microscope), XRD (X-ray powder diffraction), FTIR/DRS (fourier transform infrared spectroscopy/diffuse reflectance), XPS (X-ray photoelectron spectroscopy), and Raman spectroscopy in our earlier publication were presented [30]. The presence of nitrogen in the modified titania sample was confirmed by FTIR analysis. The narrow bands at $1640 \mathrm{~cm}^{-1}$ and $1440 \mathrm{~cm}^{-1}$ are attributed to the hydroxyl $(\mathrm{OH})$ and ammonium $\left(\mathrm{NH}_{4}{ }^{+}\right)$groups, respectively, while the band at $1536 \mathrm{~cm}^{-1}$ could be assigned to either $\mathrm{NH}_{2}$ or $\mathrm{NO}_{2}$ and $\mathrm{NO}$ groups. The sample was also studied by Raman spectroscopy. The Raman spectra of the sample exhibit four distinct peaks located at $145 \mathrm{~cm}^{-1}, 393 \mathrm{~cm}^{-1}, 514 \mathrm{~cm}^{-1}$, and $646 \mathrm{~cm}^{-1}$; those bands correspond to the anatase phase of $\mathrm{TiO}_{2}[30]$.

Table 1. Structural and textural parameters of $\mathrm{N}$-modified $\mathrm{TiO}_{2}$.

\begin{tabular}{ccccc}
\hline Photocatalyst & $\begin{array}{c}\text { Local Mean Crystallite } \\
\text { Size According to TEM } \\
{[\mathrm{nm}]}\end{array}$ & $\begin{array}{c}\text { Global Mean Crystallite } \\
\text { Size According to XRD } \\
{[\mathrm{nm}]}\end{array}$ & $\begin{array}{c}\text { Mean Particle Size According to } \\
\text { DLS (Dynamic Light Scattering) } \\
{[\mathrm{nm}]}\end{array}$ & $\begin{array}{c}\mathbf{S}_{\text {BET }} \\
{\left[\mathbf{m}^{2} / \mathrm{g}\right]}\end{array}$ \\
\hline $\mathrm{TiO}_{2} / \mathrm{N}$ & 6.1 & 10.8 & 167.6 & 235 \\
\hline
\end{tabular}

\subsection{Specimen Preparation}

The specimens $40 \cdot 40 \cdot 160 \mathrm{~mm}^{3}$ and $80 \cdot 40 \cdot 10 \mathrm{~mm}^{3}$ were produced according to EN 196-1 with a water to binder ratio $(w / b)=0.4$ and cement to standard sand ratio of 1:3. Cement was replaced by catalyst in 1,3, and $5 \mathrm{wt} \%$ by mass of cement. Samples without replacement were produced as a reference. For each type of mortar, 6 specimens were produced. Masses needed for the preparation of 3 specimens are presented in Table 2 .

Table 2. Mass of materials used for the production of three $40 \cdot 40 \cdot 160 \mathrm{~mm}^{3}$ mortar specimens.

\begin{tabular}{cccc}
\hline \multirow{2}{*}{ Materials } & \multicolumn{3}{c}{ Mass of Used Materials [g] } \\
\cline { 2 - 4 } & $\mathbf{1 \%}$ & $\mathbf{3 \%}$ & $\mathbf{5 \%}$ \\
\hline $\mathrm{CEM} \mathrm{I} \mathrm{42.5} \mathrm{N}^{\mathbf{\%}}$ & 444.5 & 436.5 & 427.5 \\
$\mathrm{TiO}_{2} / \mathrm{N}$ & 4.5 & 13.5 & 22.5 \\
Standard sand & 1350 & 1350 & 1350 \\
Water & 180 & 180 & 180 \\
\hline
\end{tabular}


A standard mixer with a stainless steel bowl with a capacity of $5 \mathrm{dm}^{3}$ according to EN 196-1 was used. First, water was poured into a bowl, and cement was added. The mixer was started immediately at low speed (rotation $140 \mathrm{~min}^{-1}$ ) and after $30 \mathrm{~s}$, standard sand was steadily added for the next $30 \mathrm{~s}$. Afterwards, the mixer was switched to the higher speed $\left(285 \mathrm{~min}^{-1}\right)$ for an additional $30 \mathrm{~s}$. To remove all the mortar adhering to the wall and the bottom part of the bowl, the mixer was stopped for $90 \mathrm{~s}$. In the end, the mixing was continued at high speed for $60 \mathrm{~s}$. The specimens were molded immediately after the preparation. The first layer of mortar was poured into the mold situated on the jolting table and then compacted. The second layer of mortar was poured on the first layer and compacted. The excess mortar was struck off with the straight metal edge. Casting molds containing fresh samples were wrapped with stretch film and stored at room conditions for $24 \mathrm{~h}$. All specimens were demolded after 1 day and were cured in tap water for the next 27 days.

\subsection{Compressive and Flexural Strength Measurements}

After $28 \mathrm{~d}$, specimens were tested for their flexural and the compressive strength. The flexural and the compressive strength measurements were carried out following EN 196-1. For each mortar type, six $40 \cdot 40 \cdot 160 \mathrm{~mm}^{3}$ specimens were tested for the flexural strength. The prism halves (after the test of flexural strength) were tested for compressive strength, so for each mortar type, 12 specimens were tested. A standard testing machine (ToniNORM 2010.040, Toni/Technik, Berlin, Germany) was used both for the flexural and the compressive strength measurements.

\subsection{Setting Time (Vicat Needle Test)}

The setting of cement and its rate affects the open time of the mortar. In this study, the influence of the addition of the catalyst on the setting time of cement was tested. The Vicat Apparatus is a device that is used to determine the setting time of the cement paste. In this study, an automatic device ToniSET COMPACT version 05/00, which did 6 parallel tests, was used for determining the setting time. For each mortar type, 2 specimens were tested. Mortar preparation and the setting time measurements were run according to the EN 196-3 standard. During the measurement, the specimens were kept at $20{ }^{\circ} \mathrm{C}$. The water to binder ratio of paste used for the setting time test was $w / b=0.3$. The time when the needle stopped $6 \mathrm{~mm}$ from the base plate was recorded as the time for the initial setting. The final setting was defined as the time when the needle only made a $0.5 \mathrm{~mm}$ mark on the surface.

\subsection{Hydration Heat Measurements}

Calorimetry data were obtained from externally mixed pastes containing $40 \mathrm{~g}$ of cement and $16 \mathrm{~g}$ of water, in at least a twofold determination. Data points were recorded every $60 \mathrm{~s}$ at $20^{\circ} \mathrm{C}$ (Isothermal heat flow calorimeter MC-CAL100, C3 Analysentechnik, C3 Prozess und Analystechnik, Haar, Germany).

\subsection{Zeta Potential Measurements}

A Zeta and Titration 310 instrument from Dispersion Technology was used for the zeta potential measurements without the dilution of samples, which to some extent avoided the differences in the hydration and surface properties between diluted and original samples. First, $16 \mathrm{~g}$ of water was added to $40 \mathrm{~g}$ of cement and mixing for $20 \mathrm{~s}$. As the background, the centrifuged water from such prepared mortars was used. The average particle sizes of cement amounted to $9 \mu \mathrm{m}$.

\subsection{NOx Decomposition}

The photocatalytic activity of the prepared plates of cement mortar toward the degradation of air pollutions was also proved. In our previous works [31,32], the gaseous NO $(1.989 \mathrm{vppm} \pm 0.040 \mathrm{ppm}$, Air Liquide) was used as model pollution in photocatalytic tests. NOx removal was evaluated using the experimental installation, whose scheme is presented in Figure 1. 


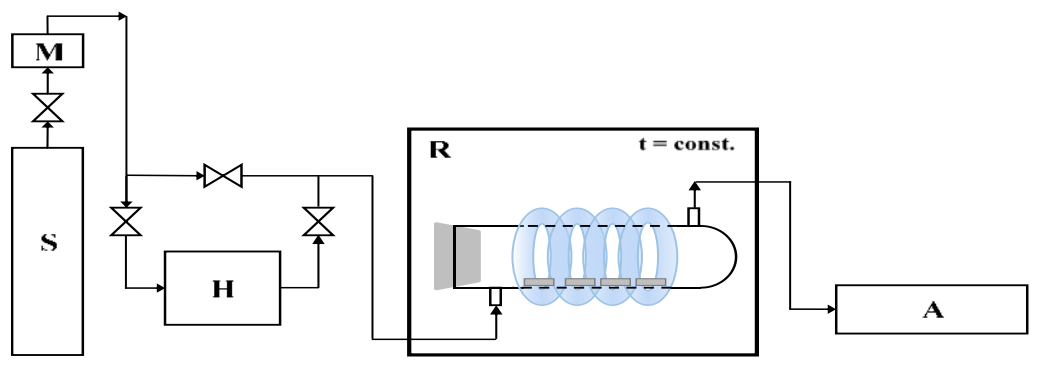

Figure 1. The scheme of installation to the photocatalytic removal of NOx (S-the source of pollution; $\mathrm{M}$-mass flower; $\mathrm{H}$-humidifier; $\mathrm{R}$ - photocatalytic reactor with irradiation source; A-NOx analyzer).

The studied plate of cement mortar (one at dimensions of $80 \times 40 \times 10 \mathrm{~mm}^{3}$ ) was placed in the central part of a cylindrical reactor (Pyrex glass; $\varnothing \times \mathrm{H}=9 \times 32 \mathrm{~cm}^{2}$ ), and the reactor was tightly closed. The NO was diluted with humidified synthetic air in a ratio of 1:1. The oxygen and water molecules were necessary for the formation of oxidative species, which are essential in the photocatalytic reactions. The polluted air flowed through the reactor continuously with a rate of $500 \mathrm{~cm}^{3} / \mathrm{min}$. At the beginning of the process, the dark conditions were maintained until NO concentration reached equilibrium (about 1 ppm during about $35 \mathrm{~min}$ ). Then, the UV lamps were turned on for $30 \mathrm{~min}$. The irradiation sources surrounded the reactor and were characterized by the cumulative intensity of $100 \mathrm{~W} / \mathrm{m}^{2} \mathrm{UV}$ and $4 \mathrm{~W} / \mathrm{m}^{2}$ VIS. The temperature of the whole system was stable at the level of $22{ }^{\circ} \mathrm{C}$ by using a thermostatic chamber. The $\mathrm{NO}$ and $\mathrm{NO}_{2}$ concentrations were continuously measured in the outlet of the reactor using chemiluminescent NOx analyzer (T200, Teledyne). All measurements were repeated three times, and errors were $2 \%$.

\section{Results}

\subsection{Compressive and Flexural Strength}

The compressive and the flexural strength of pure cement and cement with the addition of 1,3 and $5 \mathrm{wt} \% \mathrm{TiO}_{2} / \mathrm{N}$ specimens were measured. The obtained results are presented in Figure $2 \mathrm{a}, \mathrm{b}$. As it can be seen in Figure 2a, the value of the compressive strength of unmodified cement amounted to $53 \mathrm{MPa}$ (red line), while the addition of 1,3 , and $5 \mathrm{wt} \%$ of $\mathrm{TiO}_{2} / \mathrm{N}$ increased the compressive strength of the specimens in all cases. The highest value of the compressive strength was observed for specimens with $1 \mathrm{wt} \%$ of $\mathrm{TiO}_{2} / \mathrm{N}$ and amounted to $57.4 \mathrm{MPa}$. The lowest increase of the compressive strength was found for a specimen with the addition of $5 \mathrm{wt} \%$ of $\mathrm{TiO}_{2} / \mathrm{N}$. Similar behaviour occurred during the flexural strength measurements. As can be seen in Figure $2 b$, the value of the flexural strength of unmodified cement amounted to $6.92 \mathrm{MPa}$ (red line). Analogous as in the case of the compressive strength, the addition of 1,3 and $5 \mathrm{wt} \%$ of $\mathrm{TiO}_{2} / \mathrm{N}$ increased the flexural strength of the specimens in all cases. The highest value of the flexural strength was observed for a specimen with $1 \mathrm{wt} \%$ of $\mathrm{TiO}_{2} / \mathrm{N}$ and amounted to $7.60 \mathrm{MPa}$. The lowest increase of flexural strength was obtained using specimen with addition of $5 \mathrm{wt} \%$ of $\mathrm{TiO}_{2} / \mathrm{N}$.

The mechanical properties (the compressive and the flexural strength) of cement strongly depend on the amount of used titanium dioxide. Wang et al. [33] discovered that with the incorporation of $\mathrm{TiO}_{2}$ nanoparticles, the strength firstly showed a fast increase compared with the ordinary mortar until the dosage of $\mathrm{TiO}_{2}$ nanoparticles reached up to $2 \mathrm{wt} \%$, and then the rate of this increase slowed down. The strength of the cement mortar is closely related to the amount of ettringite and C-S-H gels, and the existence of nanoparticles facilitates the cement hydration, thereby producing more hydration products. In addition to the filler property of nanoparticles to fill the pores in C-S-H gels, it is well known that nanoparticles have a large surface area to volume ratio, and hence, the additional surface area turns out to be an appropriate place for hydration products to precipitate. Nanoparticles enable the formation of a bond between itself and C-S-H gels. As a result, the strength can be accordingly improved. However, there is also an undesirable effect due to the large ratio of surface area to volume, since nanoparticles 
can glue together, many nanoparticle clusters, and the strength that can be generated is very weak, leading to a heterogeneous microstructure.

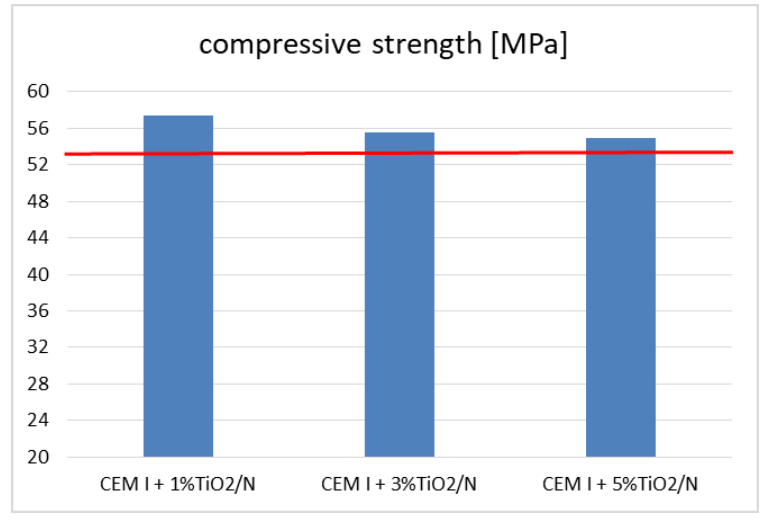

(a)

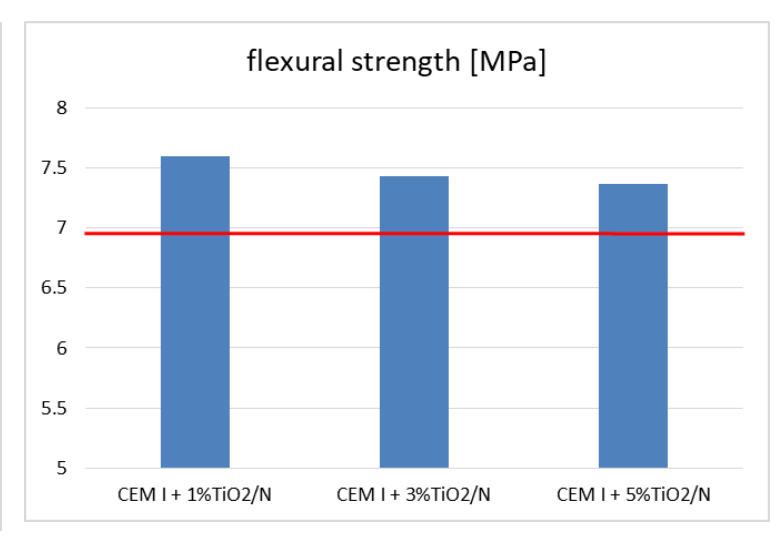

(b)

Figure 2. (a) Compressive and (b) flexural strength of CEM I $42.5 \mathrm{~N}$ with the addition of 1, 3, and $5 \mathrm{wt}$ $\%$ of photocatalyst $\mathrm{TiO}_{2} / \mathrm{N}$. In the red line, the compressive strength (53 MPa) and flexural strength (6.92 $\mathrm{MPa})$ of pure CEM I 42.5 was presented.

Beyond $3 \mathrm{wt} \%$ nano- $\mathrm{TiO}_{2}$, the cementing system seems to be saturated, and the poor dispersion of the nanoparticles generated by their high surface area may create weak zones in the system. In addition, it could also enhance the particle packing density of the blended cement by filling up the nanopores and reducing both the larger pores as well as the overall porosity of the mix. This decreased the total specific volume of the pores; the refinement of the pore structure when up to $3 \mathrm{wt} \%$ nano- $\mathrm{TiO}_{2}$ is used as a partial replacement of cement was also reported by Praveenkumar et al. [34] and Nazari and Riahi $[35,36]$.

\subsection{Setting Time}

The initial and the final setting time of tested specimens is presented in Table 3. As can be seen, with the increasing addition of $\mathrm{TiO}_{2} / \mathrm{N}$ to cement, the initial setting time decreased. In the case of the specimens modified by the addition of $5 \mathrm{wt} \%$ of $\mathrm{TiO}_{2} / \mathrm{N}$, the initial setting time was $40 \mathrm{~min}$ faster than that for unmodified cement. The same behavior was observed for the final setting time. With an increasing addition of $\mathrm{TiO}_{2} / \mathrm{N}$ to cement, the final setting time decreased. Specimens of cement with an addition of $5 \mathrm{wt} \%$ of $\mathrm{TiO}_{2} / \mathrm{N}$ showed a final setting time that was about $57 \mathrm{~min}$ faster in comparison to the unmodified cement. A similar observation was made by Hernández-Rodríguez et al. [37]; they added commercial $\mathrm{TiO}_{2}$ P25 to CEM I $52.5 \mathrm{R}$ and the results showed that the photocatalysts act as a setting accelerator.

Table 3. The values of initial and final setting time of CEM I and CEM I with the addition of 1, 3, and 5 wt $\%$ of $\mathrm{TiO}_{2} / \mathrm{N}$ photocatalysts.

\begin{tabular}{ccc}
\hline Samples & The Initial Setting Time [min] & The Final Setting Time [min] \\
\hline CEM I $42.5 \mathrm{~N}$ & 218 & 305 \\
$\mathrm{CEM}+\mathbf{1} \mathrm{wt} \% \mathrm{TiO}_{2} / \mathrm{N}$ & 217 & 310 \\
$\mathrm{CEM}+\mathbf{3} \mathrm{wt} \% \mathrm{TiO}_{2} / \mathrm{N}$ & 207 & 275 \\
$\mathrm{CEM}+\mathbf{5} \mathrm{wt} \% \mathrm{TiO}_{2} / \mathrm{N}$ & 178 & 248 \\
\hline
\end{tabular}

\subsection{Hydration Heat}

In Figure 3, the isothermal calorimetry results of unmodified cement and cement modified by the addition of 1,3 , and $5 \mathrm{wt} \%$ of $\mathrm{TiO}_{2} / \mathrm{N}$ photocatalysts were presented. 


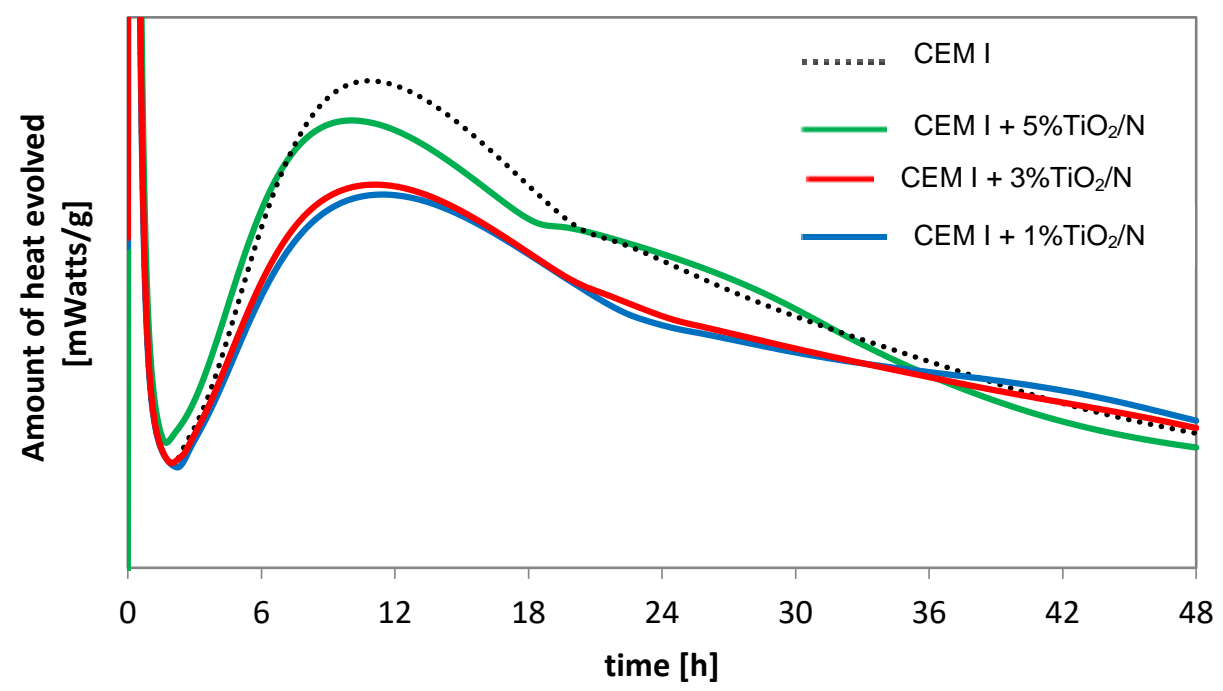

Figure 3. Isothermal calorimetry results for cement modified by the addition of 1,3 , and $5 \mathrm{wt} \%$ of $\mathrm{TiO}_{2} / \mathrm{N}$ to deionized water at a water to binder ratio $(\mathrm{w} / \mathrm{b})=0.4$.

According to the literature, there are five stages of heat for a typical Portland cement $[38,39]$. The addition of modified titanium dioxide into the cement influences hydration heat; the paste with the addition of $\mathrm{TiO}_{2} / \mathrm{N}$ showed less heat generated up to $20 \mathrm{~h}$ compared to the unmodified cement.

\subsection{Zeta Potential Measurements}

The average value of zeta potential amounted to $-5.01 \mathrm{mV}$ for unmodified cement mortar and $-4.90 \mathrm{mV},-4.69 \mathrm{mV}$ and $-5.94 \mathrm{mV}$ for cement mortars modified by the addition of 1,3 , and $5 \mathrm{wt} \%$ of $\mathrm{TiO}_{2} / \mathrm{N}$, respectively.

It is worth pointing out that $\mathrm{TiO}_{2}$ photocatalysts are characterized by a negative charge in high $\mathrm{pH}$ medium. In our previous work [40], it was proven that the point of zero charge of $\mathrm{TiO}_{2} / \mathrm{N}$ is about 5.8. Namely, the $\mathrm{TiO}_{2} / \mathrm{N}$ surface appeared to be positively charged at $\mathrm{pH}<5.8$, whereas it was negatively charged at $\mathrm{pH}>5.8$. The application of $\mathrm{TiO}_{2} / \mathrm{N}$ with highly alkaline cement resulted in the presence of a negatively charged form of $\mathrm{TiO}_{2} / \mathrm{N}$ particles.

Zingg et al. [41] concluded that the phases $\mathrm{C}_{3} \mathrm{~S}$ and C-S-H are positively charged, whereas the ettringite is negatively charged. During the initial stage of cement hydration, the aluminate reacts with water and sulfate, forming a gel-like material (ettringite) surrounding the cement grains. The negative values of zeta potential at the beginning of the hydration process confirmed it.

\subsection{NOx Decomposition}

In Figure 4, the photocatalytic activity of unmodified and modified cements is presented. The activity of obtained materials during NO removal was tested. The mechanism of photocatalytic $\mathrm{NO}$ removal is as follows [42]. Initially, active oxidizing groups are generated at the $\mathrm{TiO}_{2}$ surface (reactions 1-3):

$$
\begin{gathered}
\mathrm{O}_{2}+\mathrm{e}^{-} \rightarrow \mathrm{O}_{2}^{-} \\
\mathrm{OH}^{-}+\mathrm{h}^{+} \rightarrow \cdot \mathrm{OH} \\
\mathrm{H}^{+}+\mathrm{O}_{2}^{-} \rightarrow \mathrm{HO}_{2} .
\end{gathered}
$$

The action of these moieties on $\mathrm{NO}$ molecules leads to their oxidation to the form of $\mathrm{NO}_{2}$, followed by the formation of nitric(III) and (V) acids (reactions 4-6):

$$
\mathrm{NO}+\mathrm{HO}_{2}^{-} \rightarrow \mathrm{NO}_{2}+\cdot \mathrm{OH}
$$




$$
\begin{aligned}
& \mathrm{NO}_{2}+\cdot \mathrm{OH} \rightarrow \mathrm{HNO}_{3} \\
& \mathrm{NO}+\cdot \mathrm{OH} \rightarrow \mathrm{HNO}_{2} .
\end{aligned}
$$

In Figure 4a, the decreasing of NOx concentration [ppm] is presented. During the first $40 \mathrm{~min}$, the equilibrium of $\mathrm{NO}$ was obtained. After $40 \mathrm{~min}$, the UV light was switch on, and it is possible to observe that the NOx concertation decreased. The irradiation takes $30 \mathrm{~min}$, and after this time, the light was switched off. Figure $4 \mathrm{~b}$ presents the NOx degradation in percent after $30 \mathrm{~min}$ of UV light irradiation. The reference sample, pure CEM I, showed the removal of NOx on the level of about $6.3 \%$. The same observation concerning the blank sample was presented by $\mathrm{Xu}$ et al. [43]. They found that using reference cement composites without any $\mathrm{TiO}_{2}$, the $\mathrm{NOx}$ concentration slowly decreased by $6 \%$ during $15 \mathrm{~min}$ of irradiation. It is worth pointing out that in our studies, the photolysis of tested gas amounted to $1.3 \%$ under the same conditions and the same irradiation source. The application of nitrogen-modified $\mathrm{TiO}_{2}$ in cement mortars involved the degradation of NOx on the photocatalytic path, which can be observed as the unambiguous decrease of NOx concentration directly after turning on the irradiation. The increase of $\mathrm{TiO}_{2} / \mathrm{N}$ loading in cement matrix caused the increase of the $\mathrm{NOx}$ degradation rate from $14.2 \%$ for $\mathrm{CEM} \mathrm{I}+1 \mathrm{wt} \% \mathrm{TiO}_{2} / \mathrm{N}$ to $22.9 \%$ for CEM I $+5 \mathrm{wt} \% \mathrm{TiO}_{2} / \mathrm{N}$. Apart from the influence of the photocatalyst dose in the cement matrix, the accessible surface area of the photocatalyst is essential for the photocatalytic effectiveness [10]. Therefore, we did not observe a proportional increase of $\mathrm{NOx}$ degradation rate with the higher $\mathrm{TiO}_{2} / \mathrm{N}$ loading. However, it appeared that the nitrogen-modified photocatalyst might be used as an additive to cement materials to increase its air purification properties. Moreover, in Table 4, the $\mathrm{NO}$ removal and $\mathrm{NO}_{2}$ formation during the photocatalytic oxidation of $\mathrm{NO}$ are presented.

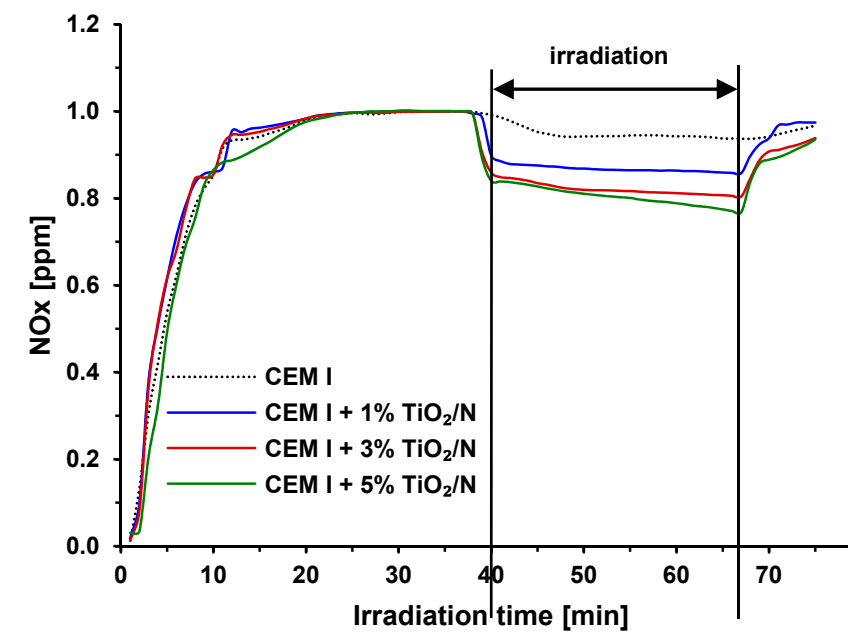

(a)

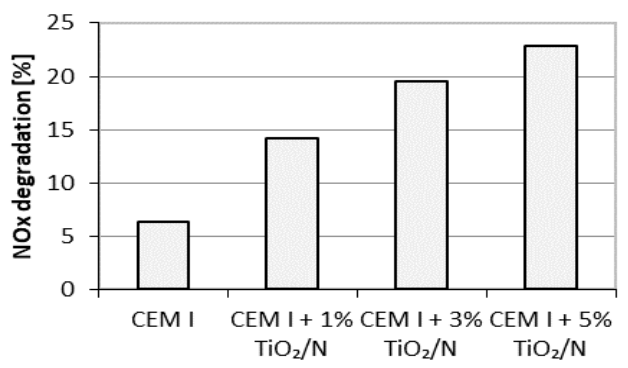

(b)

Figure 4. (a) Graph of NOx [ppm] decomposition and (b) NOx degradation [\%] on CEM I samples, and cements modified by the addition of 1,3 , and $5 \mathrm{wt} \%$ of $\mathrm{TiO}_{2} / \mathrm{N}$ under UV light irradiation.

Table 4. The $\mathrm{NO}$ removal and $\mathrm{NO}_{2}$ creation during $\mathrm{NO}$ photooxidation with cement modified by $\mathrm{TiO}_{2} / \mathrm{N}$.

\begin{tabular}{cccc}
\hline Sample & NO Removal [ppm] & $\mathbf{N O}_{\mathbf{2}}$ Formation [ppm] & NOx Removal [ppm] \\
\hline Photolysis & 0.023 & 0.013 & 0.010 \\
CEM I & 0.057 & 0.009 & 0.048 \\
$\mathrm{CEM} \mathrm{I} \mathrm{+} \% \mathrm{TiO}_{2} / \mathrm{N}$ & 0.141 & 0.030 & 0.111 \\
$\mathrm{CEM} \mathrm{I} \mathrm{+} \mathrm{3 \%} \mathrm{TiO} / \mathrm{N}$ & 0.179 & 0.025 & 0.154 \\
$\mathrm{CEM} \mathrm{I} \mathrm{+} \mathrm{5 \%} \mathrm{TiO} / \mathrm{N}$ & 0.211 & 0.032 & 0.179 \\
\hline
\end{tabular}


In Table 5, the initial photodegradation rates are presented. It was calculated 5 min after switching on the UV light. This value was calculated as $\mu \mathrm{g}$ of $\mathrm{NO}$ removal, $\mathrm{NO}_{2}$ creation, and $\mathrm{NOx}$ total removal on the surface of modified cement plates $\left[\mathrm{cm}^{2}\right]$ during the time of UV light irradiation [h]. As it can be seen, the highest vales of $\mathrm{NO}$ removal, $\mathrm{NO}_{2}$ creation, and $\mathrm{NOx}$ total removal were when the cement was modified by the addition of $5 \mathrm{wt} \%$ of $\mathrm{TiO}_{2} / \mathrm{N}$.

Table 5. The initial photodegradation rate for modified cement during NO removal, NO creation, and NOx total removal.

\begin{tabular}{|c|c|c|c|}
\hline Sample & $\begin{array}{l}\text { NO Removal } \\
{\left[\mu \mathrm{g} / \mathrm{cm}^{2} / \mathrm{h}\right]}\end{array}$ & $\begin{array}{c}\mathrm{NO}_{2} \text { Formation } \\
{\left[\mu \mathrm{g} / \mathrm{cm}^{2} / \mathrm{h}\right]}\end{array}$ & $\begin{array}{c}\text { NOx Total Removal } \\
{\left[\mu \mathrm{g} / \mathrm{cm}^{2} / \mathrm{h}\right]}\end{array}$ \\
\hline Photolysis & 0.289 & 0.038 & 0.251 \\
\hline CEM I & 0.315 & 0.091 & 0.224 \\
\hline $\mathrm{CEM} \mathrm{I}+1 \% \mathrm{TiO}_{2} / \mathrm{N}$ & 2.530 & 0.622 & 1.908 \\
\hline $\mathrm{CEM} \mathrm{I}+3 \% \mathrm{TiO}_{2} / \mathrm{N}$ & 3.145 & 0.496 & 2.649 \\
\hline $\mathrm{CEM} \mathrm{I}+5 \% \mathrm{TiO}_{2} / \mathrm{N}$ & 3.403 & 0.651 & 2.752 \\
\hline
\end{tabular}

The similar results of NOx photocatalytic degradation on cement materials were observed by other authors as well. It was reported [13] that $5 \% \mathrm{TiO}_{2}$ replacement by the mass of cement in cement pastes allowed decreasing the NO concentration from $1 \mathrm{ppm}$ to about $0.7 \mathrm{ppm}$. The results were calculated after $3 \mathrm{~h}$ of exposure to UV irradiation, because it was the necessary time to achieve the relative stasis in NO concentration. Jimenez-Relinque et al. [21] applied $2 \%$ of commercial $\mathrm{TiO}_{2}$ with different types of cement in normalized mortars. NO gas diluted in the air was used as model pollutant with an initial concentration of $1 \mathrm{ppm} \pm 50 \mathrm{ppb}$. After $1 \mathrm{~h}$ of UV irradiation, they obtained NO photocatalytic degradation on the level of $15-30 \%$ and NOx removal in the range of $18-25 \%$, depending on the applied cement type.

In Figure 5, the lifetime of tested modified cement plates was presented. As it can be seen, there was no decrease in the photocatalytic activity of the modified cement plates. NO removal and total NOx removal are on the same level. There are only small differences between NO and NOx concentration, and this behavior suggests that with time (increasing the number of cycles), more $\mathrm{NO}_{2}$ is produced.

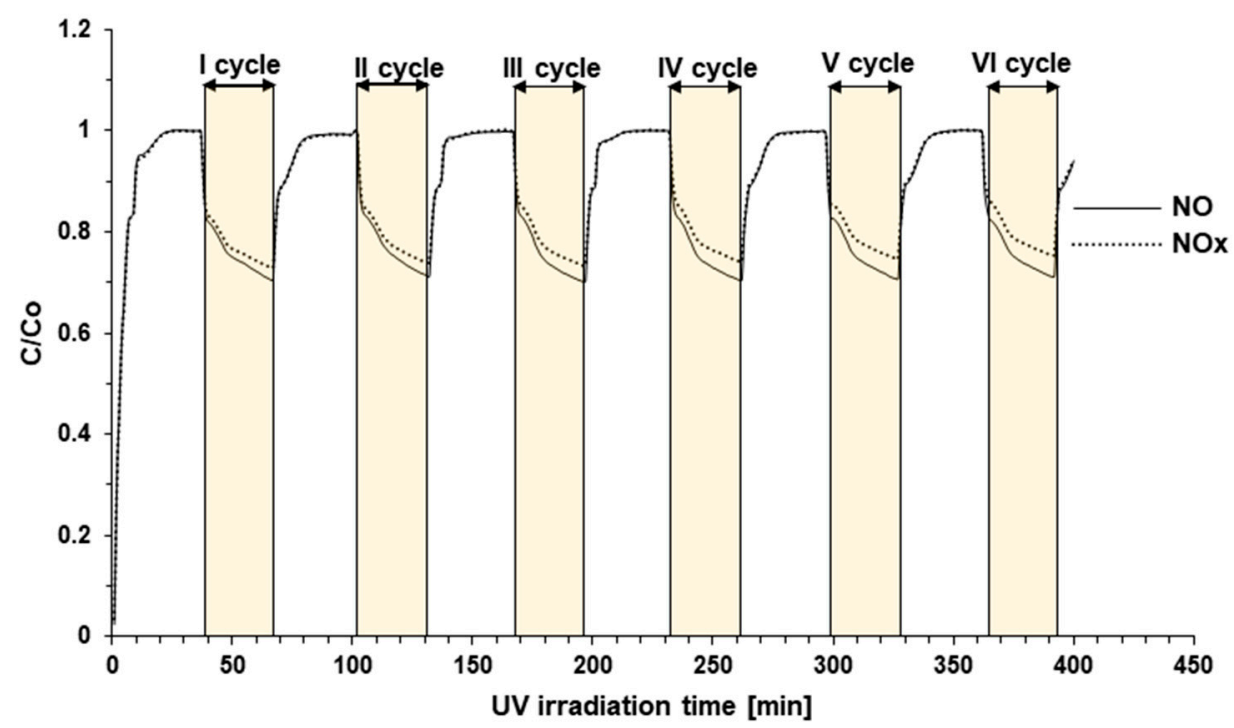

Figure 5. The lifetime of $\mathrm{CEM} \mathrm{I}+5 \mathrm{wt} \% \mathrm{TiO}_{2} / \mathrm{N}$ under six cycles of irradiation.

\section{Conclusions}

The nitrogen-modified titanium dioxide $\left(\mathrm{TiO}_{2} / \mathrm{N}\right)$ may be used as an additive to cement mortars to produce the cement with photocatalytic properties. All photocatalytic samples degraded regarding 
the NOx concentration during irradiation time, achieving a higher NOx removal rate with a higher $\mathrm{TiO}_{2} / \mathrm{N}$ dosage in cement materials. The addition of $\mathrm{TiO}_{2} / \mathrm{N}$ up to $5 \mathrm{wt} \%$ into the cement mortar did not decrease the mechanical properties but even slightly increased the compressive and the flexural strength.

Nanoparticles of $\mathrm{TiO}_{2} / \mathrm{N}$ appeared to have an influence on the cement hydration. Acceleration of the initial and the final setting time indicated that the photocatalytic particles might act as seeds for the precipitation of C-S-H. The addition of $5 \mathrm{wt} \%$ of $\mathrm{TiO}_{2} / \mathrm{N}$ into the cement mortar shortened the setting time by about $57 \mathrm{~min}$. Moreover, the presence of $\mathrm{TiO}_{2} / \mathrm{N}$ in the cement matrix caused less heat to be generated during the hydration process.

The negative charge of high solid cement mortar, which was determined based on the zeta potential, was amplified using a higher amount of $\mathrm{TiO}_{2} / \mathrm{N}$ photocatalyst, from $-4.3 \mathrm{mV}$ to $-5.5 \mathrm{mV}$ at the beginning of hydration. High $\mathrm{TiO}_{2} / \mathrm{N}$ loading in the cement matrix resulted in more negative zeta potential, because the very fine $\mathrm{TiO}_{2}$ is negatively charged at a high $\mathrm{pH}$.

Author Contributions: Conceptualization, M.J. and S.M.; methodology, M.J. and S.M.; investigation, M.J., S.M. and K.Z.; writing-original draft preparation, M.J., S.M. and K.Z.; photocatalyst preparation, A.W.M. writing-review and editing, M.J., S.M., K.Z. and D.S.; supervision, M.J and D.S.; funding acquisition, M.J. and E.K.-N.

Funding: This research was funded by the Polish National Agency for Academic Exchange within the Bekker program.

Conflicts of Interest: The authors declare no conflict of interest.

\section{References}

1. Reches, Y. Nanoparticles as concrete additives: Review and perspectives. Constr. Build. Mater. 2018, 175, 483-495. [CrossRef]

2. Stein, $\mathrm{H}$.; Stevels, J. Influence of silica on the hydration of $3 \mathrm{CaO}, \mathrm{SiO}_{2}$. J. Appl. Chem. 1964, 14, 338-346. [CrossRef]

3. Li, H.; Xiao, H.-G.; Ou, J.-P. A study on mechanical and pressure-sensitive properties of cement mortar with nanophase materials. Cem. Concr. Res. 2004, 34, 435-438. [CrossRef]

4. Li, H.; Xiao, H.-G.; Yuan, J.; Ou, J. Microstructure of cement mortar with nano-particles. Compos. B Eng. 2004, 35, 185-189. [CrossRef]

5. Land, G.; Stephan, D. Controlling cement hydration with nanoparticles. Cem. Concr. Compos. 2015, 57, 64-67. [CrossRef]

6. Karapati, S.; Giannakopoulou, T.; Todorova, N.; Boukos, N.; Antiohos, S.; Papageorgiou, D.; Chaniotakis, E.; Dimotikali, D.; Trapalis, C. $\mathrm{TiO}_{2}$ functionalization for efficient NOx removal in photoactive cement. Appl. Surf. Sci. 2014, 319, 29-36. [CrossRef]

7. Macphee, D.E.; Folli, A. Photocatalytic concretes-The interface between photocatalysis and cement chemistry. Cem. Concr. Res. 2016, 85, 48-54. [CrossRef]

8. Lucas, S.S.; Ferreira, V.M.; de Aguiar, J.B. Incorporation of titanium dioxide nanoparticles in mortars-Influence of microstructure in the hardened state properties and photocatalytic activity. Cem. Concr. Res. 2013, 43, 112-120. [CrossRef]

9. Cárdenas, C.; Tobón, J.I.; García, C.; Vila, J. Functionalized building materials: Photocatalytic abatement of NOx by cement pastes blended with $\mathrm{TiO}_{2}$ nanoparticles. Constr. Build. Mater. 2012, 36, 820-825. [CrossRef]

10. Seo, D.; Yun, T.S. NOx removal rate of photocatalytic cementitious materials with $\mathrm{TiO}_{2}$ in wet condition. Build. Environ. 2017, 112, 233-240. [CrossRef]

11. Yang, L.; Hakki, A.; Wang, F.; Macphee, D.E. Photocatalyst efficiencies in concrete technology: The effect of photocatalyst placement. Appl. Catal. B Environ. 2018, 222, 200-208. [CrossRef]

12. Guo, M.-Z.; Chen, J.; Xia, M.; Wang, T.; Poon, C.S. Pathways of conversion of nitrogen oxides by nano $\mathrm{TiO}_{2}$ incorporated in cement-based materials. Build. Environ. 2018, 144, 412-418. [CrossRef]

13. Lee, B.Y.; Jayapalan, A.R.; Bergin, M.H.; Kurtis, K.E. Photocatalytic cement exposed to nitrogen oxides: Effect of oxidation and binding. Cem. Concr. Res. 2014, 60, 30-36. [CrossRef]

14. Chen, J.; Qiu, F.; Xu, W.; Cao, S.; Zhu, H. Recent progress in enhancing photocatalytic efficiency of $\mathrm{TiO}_{2}$-based materials. Appl. Catal. A Gen. 2015, 495, 131-140. [CrossRef] 
15. Agbe, H.; Nyankson, E.; Raza, N.; Dodoo-Arhin, D.; Chauhan, A.; Osei, G.; Kumar, V.; Kim, K.-H. Recent advances in photoinduced catalysis for water splitting and environmental applications. J. Ind. Eng. Chem. 2019, 72, 31-49. [CrossRef]

16. Rimoldi, L.; Pargoletti, E.; Meroni, D.; Falletta, E.; Cerrato, G.; Turco, F.; Cappelletti, G. Concurrent role of metal $(\mathrm{Sn}, \mathrm{Zn})$ and $\mathrm{N}$ species in enhancing the photocatalytic activity of $\mathrm{TiO}_{2}$ under solar light. Catal. Today 2018, 313, 40-46. [CrossRef]

17. Li, Z.; Ding, S.; Yu, X.; Han, B.; Ou, J. Multifunctional cementitious composites modified with nano titanium dioxide: A review. Compos. Part A Appl. Sci. Manuf. 2018, 111, 115-137. [CrossRef]

18. Rahim, A.; Nair, S.R. Influence of nano-materials in high strength concrete. J. Chem. Pharm. Sci. 2016, 974, 15-21.

19. Han, B.; Li, Z.; Zhang, L.; Zeng, S.; Yu, X.; Han, B.; Ou, J. Reactive powder concrete reinforced with nano $\mathrm{SiO}_{2}$-coated $\mathrm{TiO}_{2}$. Constr. Build. Mater. 2017, 148, 104-112. [CrossRef]

20. Yang, L.Y.; Jia, Z.J.; Zhang, Y.M.; Dai, J.G. Effects of nano- $\mathrm{TiO}_{2}$ on strength, shrinkage and microstructure of alkali activated slag pastes. Cem. Concr. Comp. 2015, 57, 1-7. [CrossRef]

21. Jimenez-Relinque, E.; Rodriguez-Garcia, J.R.; Castillo, A.; Castellote, M. Characteristics and efficiency of photocatalytic cementitious materials: Type of binder, roughness and microstructure. Cem. Concr. Res. 2015, 71, 124-131. [CrossRef]

22. Zhao, A.; Yang, J.; Yang, E.-H. Self-cleaning engineered cementitious composites. Cem. Concr. Comp. 2015, 64, 74-83. [CrossRef]

23. Yousefi, A.; Allahverdi, A.; Hejazi, P. Effective dispersion of nano- $\mathrm{TiO}_{2}$ powder for enhancement of photocatalytic properties in cement mixes. Constr. Build. Mater. 2013, 41, 224-230. [CrossRef]

24. Lowke, D.; Gehlen, C. The zeta potential of cement and additions in cementitious suspensions with high solid fraction. Cem. Concr. Res. 2017, 95, 195-204. [CrossRef]

25. Plank, J.; Hirsch, C. Impact of zeta potential of early cement hydration phases on superplasticizer adsorption. Cem. Concr. Res. 2007, 37, 537-542. [CrossRef]

26. Jennings, H.M. Refinements to colloid model of C-S-H in cement: CM-II. Cem. Concr. Res. 2008, 38, $275-289$. [CrossRef]

27. Paul, S.C.; van Rooyen, A.S.; van Zijl, G.P.; Petrik, L.F. Properties of cement-based composites using nanoparticles: A comprehensive review. Constr. Build. Mater. 2018, 189, 1019-1034. [CrossRef]

28. Chen, J.; Kou, S.C.; Poon, C.S. Hydration and properties of nano-TiO 2 blended cement composites. Cem. Concr. Comp. 2012, 34, 642-649. [CrossRef]

29. Zhang, R.; Cheng, X.; Hou, P.; Ye, Z. Influences of nano- $\mathrm{TiO}_{2}$ on the properties of cement-based materials: Hydration and drying shrinkage. Constr. Build. Mater. 2015, 81, 35-41. [CrossRef]

30. Bubacz, K.; Choina, J.; Dolat, D.; Borowiak-Paleń, E.; Moszyński, D.; Morawski, A.W. Studies on nitrogen modified $\mathrm{TiO}_{2}$ photocatalyst prepared in different conditions. Mater. Res. Bull. 2010, 45, 1085-1091. [CrossRef]

31. Zając, K.; Janus, M.; Kuźmiński, K.; Morawski, A.W. Preparation of gypsum building materials with photocatalytic properties. A strong emphasis on waste gypsum from flue gas desulfurization. Przemyst Chem. 2016, 95, 2222-2226.

32. Janus, M.; Zając, K.; Ehm, C.; Stephan, D. Fast Method for Testing the Photocatalytic Performance of Modified Gypsum. Catalysts 2019, 9, 693-701. [CrossRef]

33. Wang, L.; Zhang, H.; Gao, Y. Effect of $\mathrm{TiO}_{2}$ Nanoparticles on Physical and Mechanical Properties of Cement at Low Temperatures. Adv. Mater. Sci. Eng. 2018. [CrossRef]

34. Praveenkumar, T.R.; Vijayalakshim, M.M.; Meddah, M.S. Strengths and durability performances of blended cement concrete with $\mathrm{TiO}_{2}$ nanoparticles and rice husk ash. Constr. Build. Mater. 2019, 217, 343-351. [CrossRef]

35. Nazari, A.; Riahi, S. The effect of $\mathrm{TiO}_{2}$ nanoparticles on water permeability and thermal and mechanical properties of high strength self-compacting concrete. Mater. Sci. Eng. A 2010, 528, 756-763. [CrossRef]

36. Nazari, A.; Riahi, S. The effects of $\mathrm{TiO}_{2}$ nanoparticles on physical, thermal and mechanical properties of concrete using ground granulated blast furnace slag as binder. Mater. Sci. Eng. A 2011, 528, 2085-2092. [CrossRef] 
37. Hernández-Rodríguez, M.J.; Santana Rodríguez, R.; Darias, R.; González Díaz, O.; Pérez Luzardo, J.M.; Doña Rodríguez, J.M.; Pulido Melián, E. Effect of $\mathrm{TiO}_{2}$ Addition on Mortars: Characterisation and Photoactivity. Appl. Sci. 2019, 9, 2598-2611. [CrossRef]

38. Taylor, P.C.; Kosmatka, G.F.; Voigt, G.F. Integrated Materials and Constructions Practices for Concrete Pavement: A State-of-the-Practice Manual. 2006. Available online: https:/intrans.iastate.edu/app/uploads/ 2018/03/imcp_manual_october2007.pdf (accessed on 15 June 2019).

39. Bullard, J.W.; Jennings, H.M.; Livingston, R.A.; Nonat, A.; Scherer, G.W.; Schweitzer, J.S.; Scrivener, K.L.; Thomas, J.J. Mechanisms of cement hydration. Cem. Concr. Res. 2011, 41, 1208-1223. [CrossRef]

40. Mozia, S.; Bubacz, K.; Janus, M.; Morawski, A.W. Decomposition of 3-chlorophenol on nitrogen modified TiO2 photocatalysts. J. Hazard. Mater. 2012, 203, 128-136. [CrossRef]

41. Zingg, A.; Winnefeld, F.; Holzer, L.; Pakusch, J.; Becker, S.; Gauckler, L.J. Adsorption of polyelectrolytes and its influence on the rheology, zeta potential, and microstructure of various cement and hydrate phases. Colloid Interface Sci. 2008, 323, 301-312. [CrossRef]

42. Ballari, M.M.; Yu, Q.L.; Brouwers, H.J.H. Experimental study of the $\mathrm{NO}$ and $\mathrm{NO}_{2}$ degradation by photocatalytically active concrete. Catal. Today 2011, 161, 175-180. [CrossRef]

43. Xu, M.; Bao, Y.; Wu, T.; Xia, T.; Clark, H.L.; Shi, H.; Li, V.C. Influence of $\mathrm{TiO}_{2}$ incorporation methods on NOx abatement in Engineered Cementitious Composites. Const. Build. Mater. 2019, 221, 375-383. [CrossRef]

(C) 2019 by the authors. Licensee MDPI, Basel, Switzerland. This article is an open access article distributed under the terms and conditions of the Creative Commons Attribution (CC BY) license (http://creativecommons.org/licenses/by/4.0/). 